\title{
Pembangunan Model Pengetahuan Kerajinan Tradisional Indonesia dengan Pendekatan On-To-Knowledge
}

\author{
Ni Luh Muryanti ${ }^{1}$, Gloria Virginia ${ }^{2}$, Budi Susanto ${ }^{3}$, Umi Proboyekti ${ }^{4}$ \\ Informatika, Universitas Kristen Duta Wacana \\ Jl. Dr. Wahidin Sudirohusodo No.5-25, Yogyakarta \\ ${ }^{1}$ luh.muryantieti.ukdw.ac.id \\ ${ }^{2}$ virginialstaff.ukdw.ac.id \\ 3budsusestaff.ukdw.ac.id \\ ${ }^{4}$ othieestaff.ukdw.ac.id
}

\begin{abstract}
Traditional crafts are works made with simple equipment and made from natural materials. Traditional crafts consist of anyaman, batik, gerabah, kain tenun, kerajinan kayu and kerajinan perak. The types of traditional crafts that exist are inversely proportional to the information available about Indonesian traditional crafts. Therefore it is very important to introduce and document traditional crafts in Indonesian society. One way to document Indonesian traditional crafts is to use the semantic web. The Semantic web is able to manage dynamic data sets and models so as to provide open access to information. Knowledge of traditional Indonesian handicrafts is represented in the form of OWL. In this study, the author uses the On-ToKnowledge methodology to build ontology of traditional Indonesian handicrafts. In the On-To-Knowledge methodology there are 5 stages, but the writer only uses 4 stages, namely the feasibility study, kick-off, refinement, and evaluation stages. The feasibility study phase aims to conduct a feasibility study of the system to be built by identifying problems, system users and use cases. The kick-off phase aims to define the ontology needs of traditional Indonesian handicrafts and the sources of knowledge used. The refinement phase aims to model the ontology of traditional Indonesian handicrafts which is carried out with several stages, namely the extraction of knowledge manually, making description logic and making T-Boxes. Evaluation is the testing phase using the HermiT reasoner in the application protégé, $D L$ Query and completeness check.
\end{abstract}

Intisari- Kerajinan tradisional adalah karya yang dibuat dengan peralatan sederhana dan berbahan alami. Kerajinan tradisional terdiri dari anyaman, batik, gerabah, kain tenun, kerajinan kayu dan kerajinan perak. Jenis kerajinan tradisional yang ada berbanding terbalik dengan informasi yang tersedia mengenai kerajinan tradisional Indonesia. Oleh karena itu sangat penting untuk memperkenalkan dan mendokumentasikan kerajinan tradisional pada masyarakat Indonesia. Salah satu cara untuk mendokumentasikan kerajinan tradisional Indonesia yaitu menggunakan semantic web. Semantic web mampu mengelola sekumpulan data dan model yang dinamis sehingga dapat memberikan keterbukaan akses infromasi. Pengetahuan tentang kerajinan tradisional Indonesia direpresentasikan ke bentuk OWL. Pada penelitian ini, penulis menggunakan metodologi On-To-Knowledge untuk membangun ontologi kerajinan tradisional Indonesia. Dalam metodologi On-To-Knowledge terdapat 5 tahapan, namun penulis hanya menggunakan 4 tahapan yaitu tahap feasibility study, kick off, refinement, dan evaluation. Tahap feasibility study bertujuan untuk melakukan studi kelayakan terhadap sistem yang akan dibangun dengan mengidentifikasi masalah, pengguna sistem dan use case. Tahap kick-off bertujuan untuk

JUTEI Edisi No.2 Volume.4 Oktober 2020

ISSN 2579-3675, e-ISSN 2579-5538

DOI 10.21460/jutei.2020.42.195 mendefinisikan kebutuhan ontologi kerajinan tradisional Indonesia dan sumber pengetahuan yang digunakan. Tahap refinement bertujuan untuk melakukan pemodelan ontologi kerajinan tradisional Indonesia yang dilakukan dengan beberapa tahap yaitu ekstraksi pengetahuan secara manual, membuat description logic dan pembuatan T-Box. Evaluasi adalah tahap pengujian menggunakan reasoner HermiT pada aplikasi protégé, DL Query dan completeness check.

Kata Kunci-Semantic web, On-To-Knowledge, Kerajinan tradisional Indonesia

\section{Pendahuluan}

Setiap daerah di Indonesia memiliki kerajinan-kerajinan yang mencerminkan kekhasan dari daerah tersebut. Hal ini memperlihatkan kekayaan kebudayaan dan karya dari masing-masing daerah di Indonesia. Kerajinan dapat dibagi menjadi dua jenis yaitu kerajinan tradisional dan kerajinan modern. Kerajinan Tradisional adalah karya yang dibuat dengan peralatan sederhana dan berbahan bahan alami [1]. Kerajinan tradisional yang terdapat di Indonesia diantaranya yaitu kerajinan gerabah, kerajinan kayu, anyaman bambu, anyaman rotan, dan lain sebagainya. Namun tidak semua masyarakat mengetahui informasi tentang kerajinan tradisional di Indonesia, hal ini disebabkan karena beragam dan banyaknya jenis kerajinan yang ada. Jenis kerajinan tradisional yang ada berbanding terbalik dengan informasi yang tersedia mengenai kerajinan tradisional Indonesia. Oleh karena itu sangat penting untuk memperkenalkan dan mendokumentasikan kerajinan tradisional pada masyarakat Indonesia.

Sistem pendokumentasian dan penyebaran informasi yang kurang baik membuat kerajinan menjadi kurang diketahui oleh masyarakat. Maka akan dibangun sebuah infrastruktur informasi untuk menampung kebudayaan Indonesia. Salah satu pendekatan yang dapat diterapkan untuk menyediakan informasi tentang kerajinan tradisional yaitu menggunakan semantic web. Semantic Web mampu mengelola sekumpulan data dan model yang dinamis sehingga dapat memberikan keterbukaan akses informasi [2].

Untuk mendukung dokumentasi objek kerajinan tradisional Indonesia berbasis Semantic Web, diperlukan tahapan pemodelan terhadap objek tersebut. Pemodelan ini 
bertujuan untuk menghasilkan rancangan representasi pengetahuan yang nantinya dapat diterapkan dalam kerangka aplikasi Semantic Web. Dalam penelitian ini akan dibahas mengenai pembangunan model pengetahuan kerajinan tradisional menggunakan metode On-To-Knowledge dan dimodelkan dengan Web Ontology Language (OWL). OWL digunakan untuk merepresentasikan makna kosakata dan relasi antar kata sehingga makna suatu informasi menjadi eksplisit [3].

Metode On-To Knowledge terdiri dari beberapa tahapan yaitu feasibility study (studi kelayakan), ontology kickoff, refinement, evaluation dan maintenance [4]. Metode On-ToKnowledge menyediakan alat yang dapat mempercepat manajemen pengetahuan dalam skala besar dalam pemrosesan informasi semantik dan akses pengguna yang lebih cepat, selektif dan berorientasi pada makna [5].

Masalah yang akan diselesaikan dalam penelitian ini adalah menerapkan hasil pemodelan kerajinan tradisional menggunakan metode On-To Knowlegde dalam kerangka aplikasi berbasis Semantic Web secara khusus dengan menggunakan standar OWL. Tujuan dari penelitian ini adalah membangun sebuah sistem berbasis semantic web yang dapat memodelkan objek kerajinan tradisional Indonesia menggunakan On-To-Knowledge. Manfaat dari penelitian ini yaitu memudahkan masyarakat untuk mendapatkan informasi terkait objek berupa kerajinan tradisional yang ada di Indonesia.

Penelitian yang dilakukan Ibrahim [6] menjelaskan tentang dengan menggunakan semantic web, informasi yang tertulis pada website tidak hanya berguna sebagai informasi yang bisa dibaca oleh manusia melainkan juga menjadi sumber informasi yang bisa diproses dan dimengerti oleh komputer. Pada dasarnya tidak ada yang bisa memastikan teknik pengorganisasian informasi apa yang paling tepat. Mengingat data digital seluruh dunia yang begitu besar di dalam web. Semantic web menawarkan sebuah solusi yang memang luar biasa bagi pemrosesan informasi di web.

Penelitian yang dilakukan Susilo, Handayani, dan Wilarso [7] menjelaskan tentang penggunaan metode ontologi untuk merepresentasikan pengetahuan dalam domain layanan TIK pada aplikasi Sipelantik di Pusintek Kementerian Keuangan menghasilkan 6 kelas pengetahuan. Uji konsistensi terhadap model ontologi dengan Pellet Reasoner menunjukkan bahwa model ontologi yang dibangun konsisten karena hubungan antar konsep didefinisikan dengan benar. Pengujian dengan uji query SPARQL telah berhasil melakukan pencarian dan pengolahan data terhadap hasil ontologi dengan berbagai variasi query berdasarkan 13 buah pertanyaan kompetensi.

Ginting, Seminar, dan Wasmana [8] dalam penelitiannya menjelaskan tentang pembangunan sistem repositori pengetahuan berbasis ontologi dan jaringan semantik dengan menggunakan metode On-To-Knowledge dilakukan penyusunan ontologi dengan menggunakan proses pengembangan ontologi dan membangun relasi dengan seluruh komponen ontologi. Diperoleh empat komponen yang terlibat dalam penyusunan ontologi yaitu tajuk subjek, pengetahuan, fakultas dan laboratorium. Metode On-ToKnowledge dianggap paling mature.

\section{II.LANDASAN TEORI.}

\section{A. Semantic Web}

Semantic Web adalah sekumpulan data yang terkait sedemikian rupa. Dapat dipahami sebagai versi panjang dari World Wide Web. Teknologi Semantic Web memungkinkan orang untuk membuat penyimpanan data di Web dan membuat data - data tersebut saling berhubungan dan berintegrasi [9].

\section{B. On-To-Knowledge}

On-To-Knowledge merupakan metodologi yang sedang berkembang terkait untuk manajemen pengetahuan berbasis ontologi [5]. Metode On-To-Knowledge terdiri dari 5 tahapan proses yaitu feasibility study (studi kelayakan), ontology kickoff, refinement, evaluation dan maintenance [4]. Gambar 1 menampilkan urutan proses pada metodologi On-ToKnowledge.

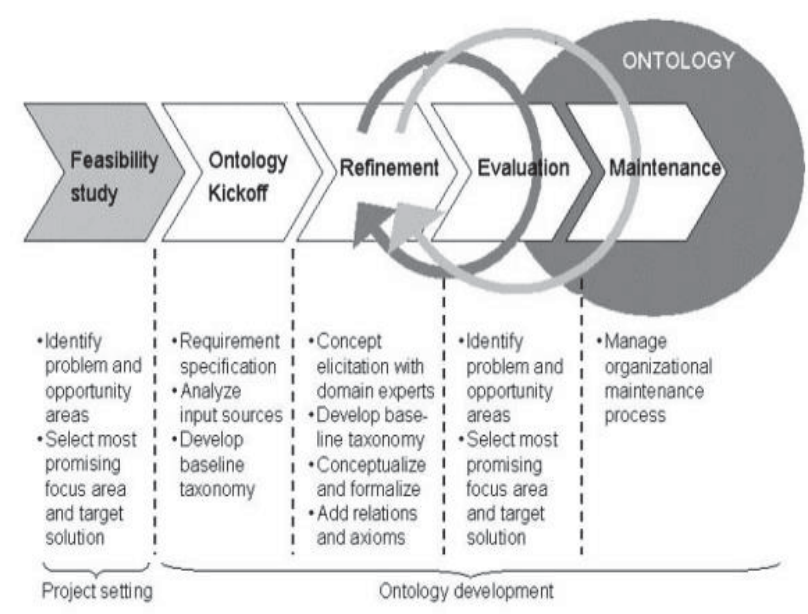

Gambar 1. Proses On-To-Knowledge [4]

1) Feasibility Study, mengidentifikasi masalah dan solusi terbaik untuk potensi masalah lainnya.

2) Ontology kickoff, menentukan spesifikasi kebutuhan sistem seperti domain dan tujuan sistem, pedoman desain, sumber pengetahuan; menganalisis sumber inputan.

3) Refinement, ada 2 aktivitas pada proses ini yaitu proses ektraksi pengetahuan dan formalisasi.

4) Evaluation, melakukan evaluasi terhadap spesifikasi kebutuhan sistem dan pengujian pada sistem.

\section{C.SPARQL}

SPARQL adalah query RDF yang digunakan untuk mengakses data pada semantic web. SPARQL dapat digunakan untuk mengekspresikan query diberbagai sumber data yang berbeda, apakah data disimpan secara native sebagai RDF atau dilihat sebagai RDF melalui middleware [10]. SPARQL memiliki 4 jenis query yaitu SELECT, ASK, CONSTRUCT, ASK dan DESCRIBE. Contoh query bisa dilihat pada Gambar 2. 


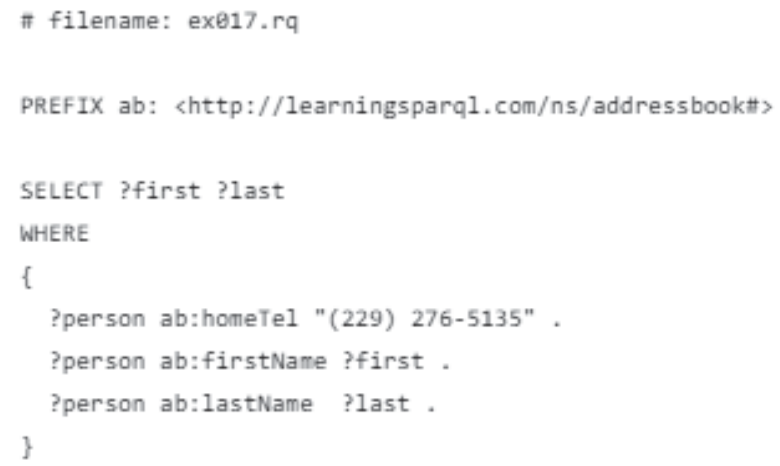

Gambar 2. Contoh query SPARQL [10]

\section{D.Web Ontology Language (OWL)}

Web Ontology Language (OWL) adalah bahasa yang populer digunakan ketika membuat ontologi. Tujuan OWL hampir sama dengan RDF Schema yaitu untuk mendefinisikan ontologi termasuk class, properti, dan hubungan untuk setiap aplikasi yang spesifik. OWL dapat menyatakan relasi yang lebih kompleks [9].

OWL terbagi menjadi tiga sub bahasa yaitu OWL-Lite, OWL DL, dan OWL Full. Vocabulary OWL menggunakan URI pada RDF, RDFS, dan OWL namespaces, dan menggunakan definisi literal XML Schema [11]. Berikut adalah class penting dalam pembuatan ontologi:

a. owl:Thing adalah classes of all things pada OWL. Semua class adalah subclass dari owl:Thing

b. owl:Class adalah class dari resources RDF dan instances dari rdfs:Class

c. owl:DatatypeProperty adalah class semua properti yang memiliki range dan instances dari rdfs:Datatype

d. owl:ObjectProperty adalah class semua properti yang memiliki range yang merupakan intances dari owl:Class

e. rdf:XMLLiteral adalah class dari semua nilai literal XML yang ditentukan dalam spesifikasi XML Schema.

Berikut ini adalah properti yang digunakan dalam pembuatan ontologi:

a. rdf:type adalah properti yang digunakan untuk menentukan bahwa sebuah resource merupakan instance dari class RDF tertentu.

b. rdfs:subClassOf untuk menentukan bahwa sebuah class merupakan subclass dari class lain sehingga semua instance dari subclass merupakan instance dari superclass.

c. rdfs:domain untuk menentukan bahwa sebuah properti memiliki domain dari class tertentu.

d. rdfs:range untuk menentukan bahwa sebuah properti memiliki rangen class tertentu.

\section{E. Description Logic}

Descripton logics (DL) adalah bahasa representasi pengetahuan yang dapat digunakan untuk mewakili pengetahuan tentang domain dengan cara yang terstruktur dan dapat dipahami dengan baik [12]. Descrption logic memberikan arti yang tepat dan tidak ambigu untuk deskripsi domain.
Knowledge base terdiri dari dua komponen yaitu TBox dan ABox. TBox berisi vocabulary domain. Vocabulary tediri dari concepts yang menunjukkan kumpulan individu dan roles yang menunjukkan hubungan antara individu. ABox berisi kalimat-kalimat dasar yang menyatakan hubungan antara individu dan konsep. Setiap pernyataan di ABox harus memiliki model dan sesuai dengan concepts description. [13]. Concept description dalam AL-language dibentuk sesuai dengan aturan sintaks dapat dilihat pada Gambar 3.

$$
\begin{array}{lll}
C, D \longrightarrow & A \mid & \text { (atomic concept) } \\
& \top \mid & \text { (universal concept) } \\
& \perp \mid & \text { (bottom concept) } \\
& \neg A \mid & \text { (atomic negation) } \\
& C \sqcap D \mid & \text { (intersection) } \\
\forall R . C \mid & \text { (value restriction) } \\
\exists R . T & \text { (limited existential quantification). }
\end{array}
$$

Gambar 3. Sintaks untuk concept description

\section{F. Protégé}

Protégé merupakan plugin OWL yang digunakan untuk mengedit ontologi dan mengakses description logic. Tools yang ada pada protégé diantaranya reasoner HermiT dan DL Query. Hermit adalah reasoner OWL pertama yang tersedia untuk umum. HermiT bertujuan untuk menentukan konsistensi ontologi dan untuk mengidentifikasi hubungan hirarki antara kelas. Alasan ini didasarkan pada kalkulus hypertableau. Ini juga menyediakan proses yang lebih cepat untuk mengklasifikasikan ontologi [14].

\section{G.Kerajinan Tradisional}

Kerajinan Tradisional adalah karya yang dibuat dengan peralatan sederhana dan berbahan bahan alami [1]. Kerajinan tradisional terdiri dari gerabah, kerajinan kayu, anyaman, kerajinan perak, dan kain tenun. Contoh hasil kerajinan berupa gerabah yaitu guci, pot bunga, kendi dan lain-lain. Kerajinan kayu terdiri dari patung dan topeng. Beberapa daerah penghasil kerajinan tradisional yang ada di Indonesia yaitu Bengkulu, DKI Jakarta, Jawa Tengah, Jawa Timur, Kalimantan Barat [15].

Beberapa kategori kerajinan tradisional yaitu:

1. Gerabah

Gerabah adalah kerajinan dari tanah liat yang pembuatannya melalui proses pembakaran dengan suhu relatif tinggi. Kasongan merupakan daerah yang populer di Yogyakarta dengan hasil produk gerabah, keramik dan tembikar [16]. Salah satu hasil produk di Kasongan yaitu patung pengantin tradisional, yang populer dengan sebutan "Loro Blonyo". Biasanya patung ini dibuat dari kayu, namun di Kasongan dibuat dari gerabah dan berfungsi sebagai penghias ruangan.

2. Kerajinan Kayu

Kerajinan kayu adalah kerajinan yang terbuat dari bahan kayu yang dihasilkan melalui keterampilan tangan manusia dengan bantuan alat seperti pisau ukir [17]. Kerajinan kayu erat kaitannya dengan seni peran dan pertunjukan di Nusantara. Salah satu contoh kerajinan berupa kayu yaitu topeng. Topeng memiliki bentuk dan fungsi yang berbedabeda di setiap daerah. 


\section{Anyaman}

Anyaman merupakan kerajinan yang berbahan dasar bambu atau rotan yang dibuat dengan cara menganyam atau dirangkai menjadi satu kesatuan sehingga menyerupai sebuah benda. Kabupaten Rejang Lebong di Bengkulu merupakan salah satu daerah penghasil kerajinan berupa anyaman. Beberapa produk yang dihasilkan di daerah ini antara lain vas bunga (tempat bunga), selepai, bakul sirih, pane tuguk dan bakul selebau [15]. Vas bunga dari Rejang Lebong terbuat dari bahan kulit bambu yang dianyam dengan motif hiasan geometris.

4. Kain Tenun

Tenun merupakan hasil kerajinan yang berupa bahan (kain) yang dibuat dari benang (kapas, sutra, dsb) dengan cara memasuk-memasukkan pakan secara melintang pada lungsin [18]. Proses menenun dapat dibagi menjadi tiga bagian yaitu membuat benang dari kapas, persiapan menenun, dan menenun.

5. Kerajinan Perak

Kerajinan perak adalah kerajinan yang terbuat dari perak. Salah satu daerah penghasil kerajinan perak yaitu wilayah kecamatan Kotagede. Fungsi kerajinan perak sebagai icon pariwisata Yogyakarta menjadi alasan penting bagi pemerintahan Kota Yogyakarta untuk mempertahankan para pelaku industri kerajinan perak di Kotagede [19].

6. Batik

Kata batik berasal dari bahasa Jawa, yaitu "tik" yang berarti titik/matik (kata kerja, membuat titik) yang kemudian berkembang menjadi istilah "batik". Batik adalah kain bergambar yang pembuatannya khusus yaitu dengan menuliskan malam pada kain dan pengolahannya diproses dengan cara tertentu yang memiliki kekhasan [20].

\section{METODOLOGI PENELITIAN}

\section{A. On-To-Knowledge}

Pada penelitian ini penulis menggunakan metode On-To Knowledge dalam pembangunan sistem untuk kerajinan tradisional Indonesia. Tahapan-tahapan metode On-To Knowledge sebagai berikut:

1. Tahap Feasibility Study

Tahap ini bertujuan untuk melakukan studi kelayakan terhadap sistem yang akan dibangun dengan mengidentifikasi masalah, pengguna sistem dan use case. Pada tahap ini juga dilakukan pengumpulan sumber informasi yang akan digunakan untuk membangun ontologi. Sistem ini melibatkan 2 aktor yaitu user dan admin. User adalah aktor yang dapat melihat data, visualisasi dan melakukan percarian terkait kerajinan tradisional Indonesia. Admin adalah aktor yang dapat melihat data, visualisasi, melakukan pencarian dan mengolah data kerajinan tradisional Indonesia. Diagram use case dapat dilihat pada Gambar 4.

\section{Tahap Kick Off}

Pada tahap ini dilakukan penentuan spesifikasi kebutuhan yang digunakan untuk membangun ontologi kerajinan tradisional Indonesia. Kebutuhan perangkat lunak dan keras yang digunakan dalam Dalam penelitian ini digunakan aplikasi protégé untuk membangun ontologi dan dalam pembangunan sistem semantic web spesifikasi software yang dibutuhkan seperti Google Chrome, Visual
Studio Code, SPARQL Server (Apache Jena Fuseki), dan Node.Js.

Sumber pengetahuan yang digunakan yaitu Album Kerajinan Tradisional (Bengkulu, DKI Jakarta, Jawa Tengah, Jawa Timur, Kalimantan Barat) [15], Album Gerabah Tradisional Kasongan Yogaykarta [16], Pengrajin Tradisional di Daerah Bali [21], Indonesia Indah: Tenunan Indonesia 3 [22].

\section{Tahap Refinement}

Pada tahap ini dilakukan pemodelan ontologi kerajinan tradisional Indonesia berdasarkan fakta-fakta dari sumber pengetahuan yang digunakan. Beberapa daftar kalimat fakta kerajinan tradisional Indonesia dapat dilihat pada Tabel 1.

TABEL I

DAFTAR KALIMAT FAKTA

\begin{tabular}{|c|l|}
\hline No & \multicolumn{1}{|c|}{ Kalimat } \\
\hline 1 & $\begin{array}{l}\text { Bakul Serampi adalah bakul yang berfungsi sebagai alat } \\
\text { takaran hasil bumi seperti beras dan sejenisnya. }\end{array}$ \\
\hline 2 & $\begin{array}{l}\text { Bakul Serampi terbuat dari bambu dan rotan dengan motif } \\
\text { anyaman bintang. }\end{array}$ \\
\hline 3 & Bakul Serampi berasal dari daerah Rejang Lebong \\
\hline
\end{tabular}

Tahap selanjutnya yaitu diubah menjadi subjek, predikat dan objek (SPO). Hasil pengelompokannya dapat dilihat pada Tabel 2.

TABEL II

HASIL PENGELOMPOKKAN SPO

\begin{tabular}{|c|l|l|}
\hline \multicolumn{1}{|c|}{ Subjek } & \multicolumn{1}{|c|}{ Predikat } & \multicolumn{1}{c|}{ Objek } \\
\hline Bakul Serampi & berfungsi & $\begin{array}{l}\text { alat takaran hasil bumi } \\
\text { seperti beras dan sejenisnya. }\end{array}$ \\
\hline Bakul Serampi & terbuat dari & bambu, rotan \\
\hline Bakul Serampi & Dengan motif & anyaman bintang \\
\hline Bakul Serampi & Berasal dari & Rejang Lebong \\
\hline
\end{tabular}

Description logic digunakan untuk membangun ontologi kerajinan tradisional Indonesia. Pembuatan description logic berdasarkan pada hasil pemodelan pengetahuan yang telah dibuat. Berikut beberapa contoh description logic objek kerajinan tradisional Indonesia:

- Kerajinan tradisional terdiri dari anyaman, batik, gerabah, kain tenun, kerajinan kayu dan kerajinan perak. KerajinanTradisional

$$
\begin{aligned}
& \sqsubseteq \text { Anyaman } \sqcup \text { Batik } \sqcup \text { Gerabah } \\
& \sqcup \text { KainTenun } \sqcup \text { KerajinanKayu } \\
& \sqcup \text { KerajinanPerak }
\end{aligned}
$$

- Anyaman adalah kerajinan tradisional yang memiliki motif kerajinan dan berbahan dasar tumbuhan.

Anyaman $\equiv$ KerajinanTradisional

$$
\begin{aligned}
& \Pi \text { (memilikiMotif. MotifKerajinan }) \\
& \Pi(\forall \text { memilikiBahan.Tumbuhan })
\end{aligned}
$$

- Gerabah adalah kerajinan tradisional yang memiliki motif dan berbahan tanah liat. 
Gerabah $\equiv$ KerajinanTradisional

$$
\begin{aligned}
& \Pi(\text { memilikiMotif. MotifKerajinan }) \\
& \Pi(\forall \text { memilikiBahan.TanahLiat })
\end{aligned}
$$

- $\quad$ Kain Tenun adalah kerajinan tradisional yang memiliki motif dan berbahan benang.

KainTenun $\equiv$ KerajinanTradisional

$$
\begin{aligned}
& \Pi(\text { memilikiMotif. Motif Kerajinan }) \\
& \Pi(\forall \text { memilikiBahan. Benang })
\end{aligned}
$$

- Kerajinan Kayu adalah kerajinan tradisional yang memiliki motif dan berbahan kayu.

KerajinanKayu

$$
\begin{aligned}
& \equiv \text { KerajinanTradisional } \\
& \Pi(\text { memilikiMotif } . \text { MotifKerajinan }) \\
& \Pi(\forall \text { memilikiBahan. Kayu })
\end{aligned}
$$

- Kerajinan Perak adalah kerajinan tradisional yang memiliki motif dan berbahan perak.

KerajinanPerak

$$
\begin{aligned}
& \equiv \text { KerajinanTradisional } \\
& \Pi(\text { memilikiMotif. Motif Kerajinan }) \\
& \Pi(\forall \text { memilikiBahan.Perak })
\end{aligned}
$$

- Bahan Kerajinan terdiri dari Bahan Nonlogam atau Bahan Logam.

BahanKerajinan

\section{$\sqsubseteq$ BahanNonlogam $\sqcup$ BahanLogam}

- Bakul Selebau adalah anyaman yang memiliki motif kerajinan hias geometris.

BakulSelebau $\equiv$ Anyaman

$$
\sqcap \text { memilikiMotif.HiasGeometris }
$$

- Bakul Selebau, Bakul Tangkai, Bokoa Iben, Niru / Teleng, Pane Tuguk, Vas Bunga adalah anyaman yang mengunakan motif hias geometris.

Anyaman $\sqcap$ (memilikiMotif. HiasGeometris)

- Delamak. Kain Ikat Badan, Kain Selendang adalah kain tenun yang menggunakan motif hias geometris.

KainTenun $\sqcap$ (memilikiMotif. HiasGeometris)

Perancangan T-Box untuk kerajinan tradisional Indonesia dapat dilihat pada Gambar 5.

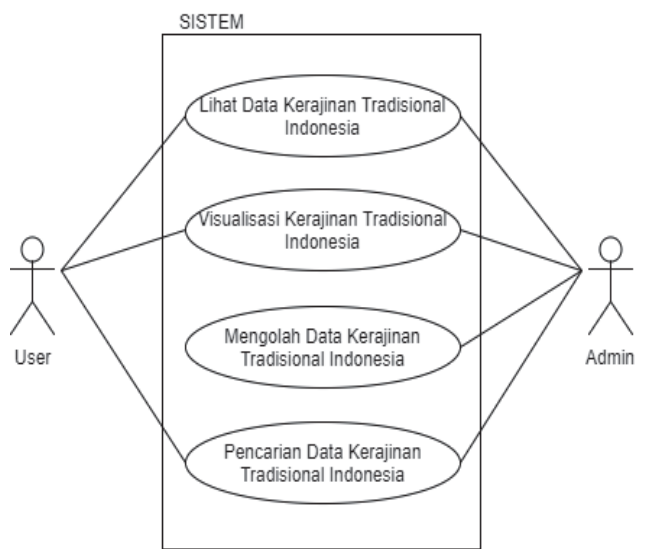

Gambar 4. Use Case Diagram

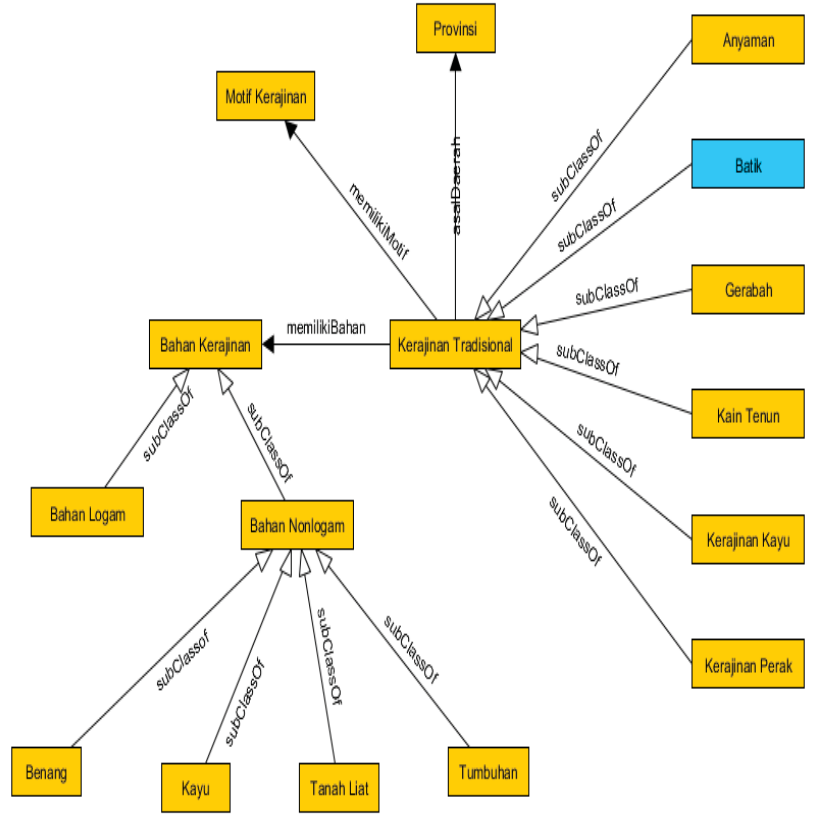

Gambar 5. Graf T-Box Ontologi Kerajinan Tradisional

4. Tahap Evaluation

Ontologi kerajinan tradisional Indonesia yang telah selesai dibangun akan dilakukan evaluasi atau pengujian. Pengujian dilakukan dengan tiga cara yaitu:

\section{- Consistency}

Pengujian konsistensi dilakukan menggunkan reasoner HermiT pada Protégé yang bertujuan untuk mengukur konsistensi ontologi yang telah dibangun. Pengujian dengan reasoner HermiT akan dilakukan pada class, object properties, dan data properties.

\section{- Validasi Ontologi}

Validasi ontologi dilakukan menggunakan DL Query berdasarkan description logic yang telah dibuat pada tahap refinement. Pengujian ini bertujuan untuk membuktikan data yang ada telah sesuai dengan data formal pada ontologi berdasarkan description logic.

\section{- Completeness}

Sebuah ontologi dapat dikatakan lengkap apabila semua data yang ada dapat dinyatakan secara eksplisit. Salah satu cara untuk menguji kelengkapan ontologi yaitu menggunakan competency questions. Competency questions merupakan parameter yang digunakan untuk menguji kelengkapan data ontologi yang berisi beberapa daftar pertanyaan yang mencakup data ontologi berdasarkan hasil ekstraksi pada tahap refinement. Tabel 3 merupakan daftar pertanyaan dan hasil yang diharapkan yang akan digunakan untuk pengujian ontologi kerajinan tradisional Indonesia. 
TABEL III

DAFTAR COMPETENCY QUESTIONS

\begin{tabular}{|c|c|c|}
\hline No & Pertanyaan & $\begin{array}{l}\text { Hasil yang } \\
\text { diharapkan }\end{array}$ \\
\hline CQ1 & $\begin{array}{l}\text { Apa saja kategori kerajinan } \\
\text { tradisional Indonesia? } \\
\text { (Pertanyaan ini bertujuan } \\
\text { untuk menunjukkan kategori } \\
\text { kerajinan tradisional } \\
\text { Indonesia) }\end{array}$ & $\begin{array}{l}\text { Sistem dapat } \\
\text { menampilkan } 4 \\
\text { kategori } \\
\text { kerajinan } \\
\text { tradisional } \\
\text { Indonesia }\end{array}$ \\
\hline CQ2 & $\begin{array}{l}\text { Apa saja yang termasuk } \\
\text { anyaman? } \\
\text { (Pertanyaan ini bertujuan } \\
\text { untuk menunjukkan individual } \\
\text { dari kelas anyaman) }\end{array}$ & $\begin{array}{l}\text { Sistem dapat } \\
\text { menampilkan } \\
22 \text { jenis } \\
\text { anyaman }\end{array}$ \\
\hline CQ3 & $\begin{array}{l}\text { Apa saja yang termasuk } \\
\text { gerabah? } \\
\text { (Pertanyaan ini bertujuan } \\
\text { untuk menunjukkan individual } \\
\text { dari kelas gerabah) }\end{array}$ & $\begin{array}{l}\text { Sistem dapat } \\
\text { menampilkan } \\
12 \text { jenis } \\
\text { gerabah }\end{array}$ \\
\hline CQ4 & $\begin{array}{l}\text { Apa saja yang termasuk } \\
\text { kain tenun? } \\
\text { (Pertanyaan ini bertujuan } \\
\text { untuk menunjukkan individual } \\
\text { dari kelas kain tenun) }\end{array}$ & $\begin{array}{l}\text { Sistem dapat } \\
\text { menampilkan } \\
28 \text { jenis kain } \\
\text { tenun }\end{array}$ \\
\hline CQ5 & $\begin{array}{l}\text { Apa saja yang termasuk } \\
\text { kerajinan kayu? } \\
\text { (Pertanyaan ini bertujuan } \\
\text { untuk menunjukkan individual } \\
\text { dari kerajinan kayu) }\end{array}$ & $\begin{array}{l}\text { Sistem dapat } \\
\text { menampilkan } \\
11 \text { jenis } \\
\text { kerajinan kayu }\end{array}$ \\
\hline CQ6 & $\begin{array}{l}\text { Apa saja yang termasuk } \\
\text { kerajinan perak? } \\
\text { (Pertanyaan ini bertujuan } \\
\text { untuk menunjukkan individual } \\
\text { dari kerajinan perak) }\end{array}$ & $\begin{array}{l}\text { Sistem dapat } \\
\text { menampilkan } 2 \\
\text { jenis kerajinan } \\
\text { perak }\end{array}$ \\
\hline CQ7 & $\begin{array}{l}\text { Apa saja kerajinan } \\
\text { tradisional Indonesia yang } \\
\text { memiliki motif tumpal? } \\
\text { (Pertanyaan ini bertujuan } \\
\text { untuk menunjukkan kerajinan } \\
\text { tradisional yang memiliki } \\
\text { motif tumpal) }\end{array}$ & $\begin{array}{l}\text { Sistem dapat } \\
\text { menampilkan } 3 \\
\text { kerajinan } \\
\text { tradisional } \\
\text { yang } \\
\text { menggunakan } \\
\text { motif tumpal }\end{array}$ \\
\hline CQ8 & $\begin{array}{l}\text { Apa saja kerajinan } \\
\text { tradisional Indonesia yang } \\
\text { menggunakan bahan dasar } \\
\text { kayu jelutung? } \\
\text { (Pertanyaan ini bertujuan } \\
\text { untuk menunjukkan kerajinan } \\
\text { tradisional yang menggunakan } \\
\text { bahan dasar kayu jelutung) }\end{array}$ & $\begin{array}{l}\text { Sistem dapat } \\
\text { menampilkan } 1 \\
\text { kerajinan } \\
\text { tradisional } \\
\text { Indonesia yang } \\
\text { menggunakan } \\
\text { bahan dasar } \\
\text { kayu jelutung }\end{array}$ \\
\hline CQ9 & $\begin{array}{l}\text { Apa saja kerajinan } \\
\text { tradisional Indonesia yang } \\
\text { berasal dari Nusa Tenggara } \\
\text { Barat? } \\
\text { (Pertanyaan ini bertujuan } \\
\text { untuk menunjukkan kerajinan } \\
\text { tradisional yang berasal dari } \\
\text { Nusa Tenggara Barat) }\end{array}$ & $\begin{array}{l}\text { Sistem dapat } \\
\text { menampilkan } 4 \\
\text { kerajinan } \\
\text { tradisional } \\
\text { Indonesia yang } \\
\text { berasal dari } \\
\text { Nusa Tenggara } \\
\text { Barat }\end{array}$ \\
\hline
\end{tabular}

radisional yang berasal dar

Barat

\section{B. Rancangan Arsitektur Aplikasi}

Gambar 6 merupakan alur diagram sistem. Halaman utama merupakan halaman yang menampilkan kebudayaan secara umun. Ketika pengguna memilih objek budaya kerajinan tradisional maka javascript akan mengirimkan request ke database SPARQL. Data pada SPARQL diolah dan dikembalikan dalam bentuk JSON. Kemudian ditampilkan menggunakan Vue Js sehingga bisa diakses pengguna melalui website.

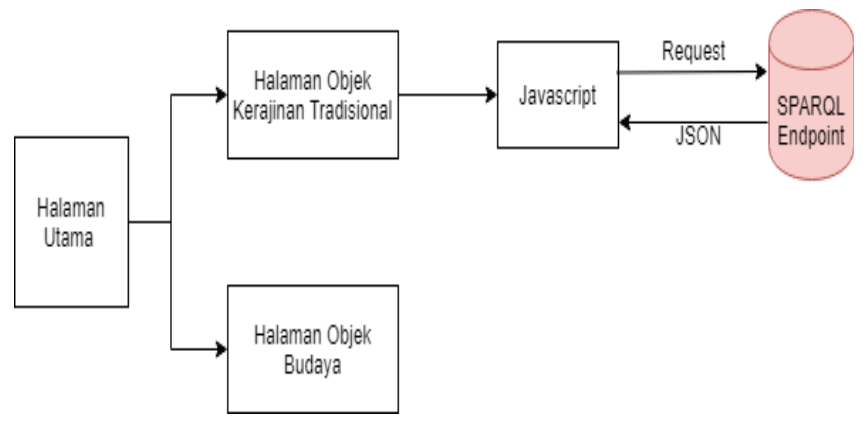

Gambar 6. Blok Diagram Sistem

\section{HASIL DAN ANALISIS}

\section{A. Implementasi Sistem}

Ontologi kerajinan tradisional Indonesia dibangun menggunakan tool Protégé berdasarkan informasi yang didapat dari buku dan melalui tahap refinement. Hasil dari tahap refinement yaitu class, instance dan relasi yang digunakan dalam pendefinisian ontologi kerajinan tradisional Indonesia. Ontologi kerajinan tradisional Indonesia disimpan dalam endpoint SPARQL Apache Jena Fuseki. Alamat url yang digunakan untuk mengakses Jena Fuseki yaitu https://app.alunalun.info/fuseki/. Untuk menampilkan data dari ontologi kerajinan tradisional Indonesia pada Jena Fuseki yaitu menggunakan query SPARQL. Hasil dari query SPARQL akan dikembalikan dalam bentuk JSON. Hasil query ini yang akan digunakan untuk menampilkan data-data kerajinan tradisional pada sistem. Sistem yang dibangun menggunakan framework Vue.js. Gambar 7 merupakan tampilan aplikasi Protégé yang digunakan untuk membangun ontologi kerajinan tradisional Indonesia.

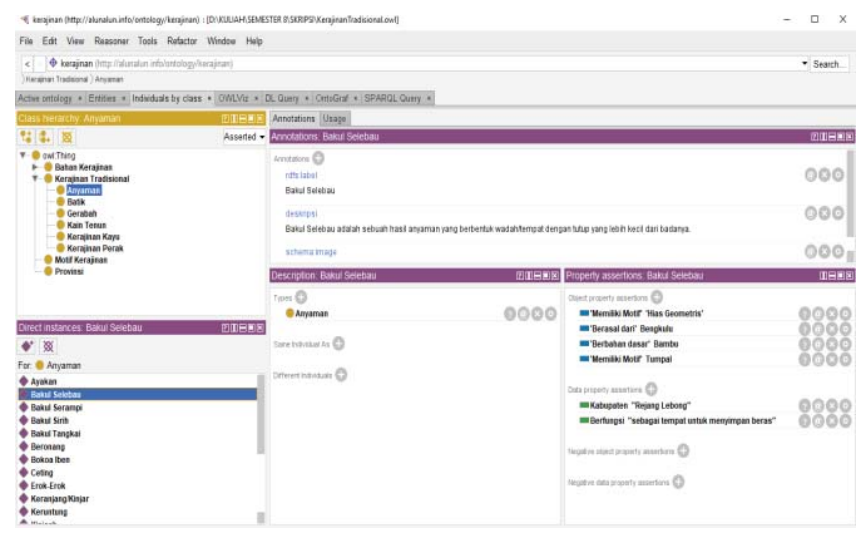

Gambar 7. Aplikasi Protégé 


\section{B. Implementasi Antarmuka}

Pada penelitian ini antarmuka yang dibangun sebagai berikut:

a. Halaman Beranda

Halaman beranda adalah halaman yang pertama kali muncul saat website diakses. Halaman beranda menampilkan kategori kerajinan tradisional yang terdiri dari anyaman, batik, gerabah, kain tenun, kerajinan kayu dan kerajinan perak. Ketika salah satu ketegori kerajinan diklik maka akan menampilkan halaman kategori kerajinan seperti pada Gambar 9. Pada bagian header terdapat beberapa menu yaitu beranda, asal daerah, bahan kerajinan, motif kerajinan, visualisasi dan kolom pencarian. Halaman beranda dapat dilihat pada Gambar 8.

\section{b. Halaman Kategori Kerajinan}

Halaman kategori kerajinan adalah halaman yang menampilkan nama - nama kerajinan berdasarkan kategori kerajinan yang dipilih pada halaman beranda. Nama kerajinan ditampilkan dalam bentuk kolom yang berisi gambar dan label nama kerajinan. Apabila gambar atau label nama kerajinan diklik akan diarahkan ke halaman yang berisi detail dari kerajinan tersebut. Halaman kategori kerajinan dapat dilihat pada Gambar 9.

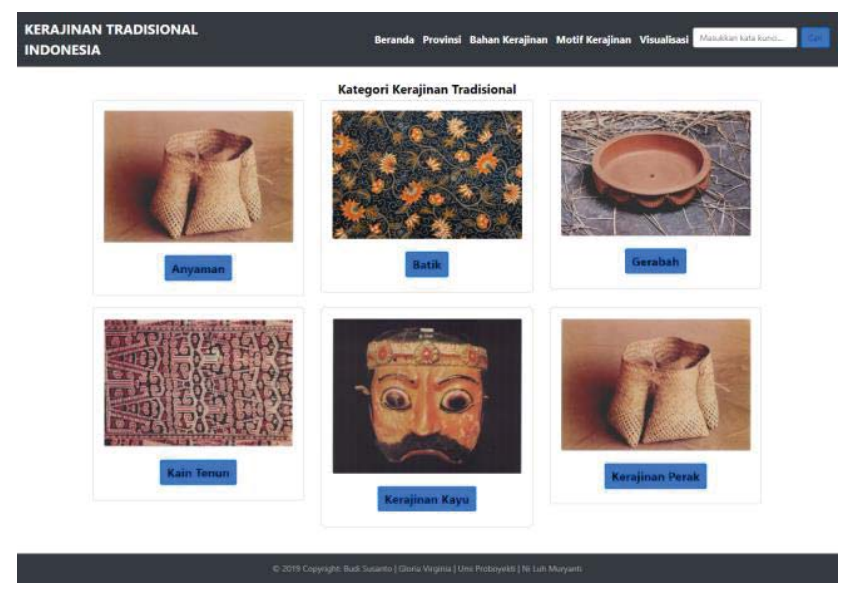

Gambar 8. Halaman Beranda

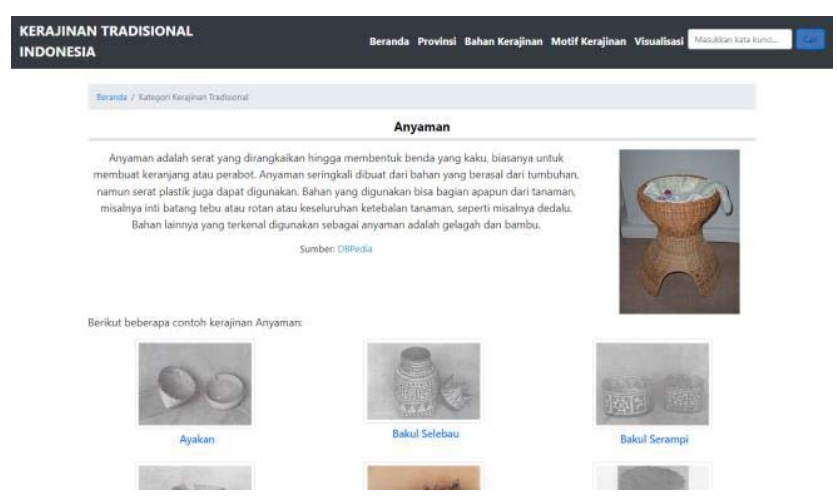

Gambar 9. Halaman Kategori Kerajinan

c. Halaman Asal Daerah

Halaman asal daerah menampilkan nama-nama provinsi. Nama provinsi ditampilkan dalam bentuk button.
Ketika salah satu nama provinsi diklik akan menampilkan daftar kerajinan yang berasal dari provinsi tersebut yang dapat dilihat pada Gambar 11 dan Gambar 12. Halaman asal daerah dapat dilihat pada Gambar 10.

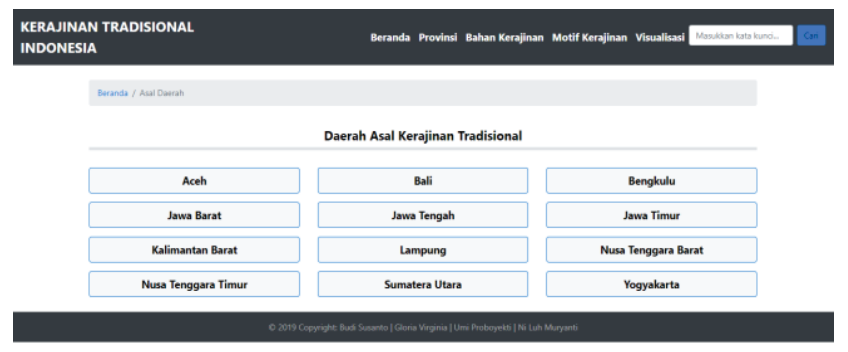

Gambar 10. Halaman Asal Daerah

\section{d. Halaman Daerah Kerajinan}

Halaman daerah kerajinan menampilkan deskripsi dari daerah tertentu dan daftar kerajinan yang berasal dari daerah tertentu. Daftar kerajinan ditampilkan dalam bentuk kolom disertai dengan gambar dari kerajinan tersebut dan dikelompokkan berdasarkan kategori kerajinan. Apabila gambar atau label nama kerajinan diklik akan diarahkan ke halaman lain yang berisi detail dari kerajinan tersebut. Halaman daerah kerajinan dapat dilihat pada Gambar 11 dan Gambar 12.

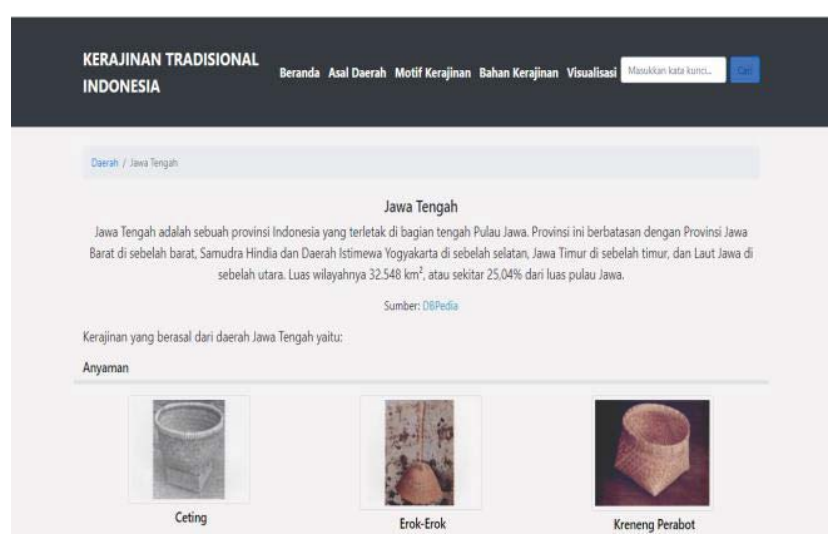

Gambar 11. Halaman Daerah Kerajinan-1

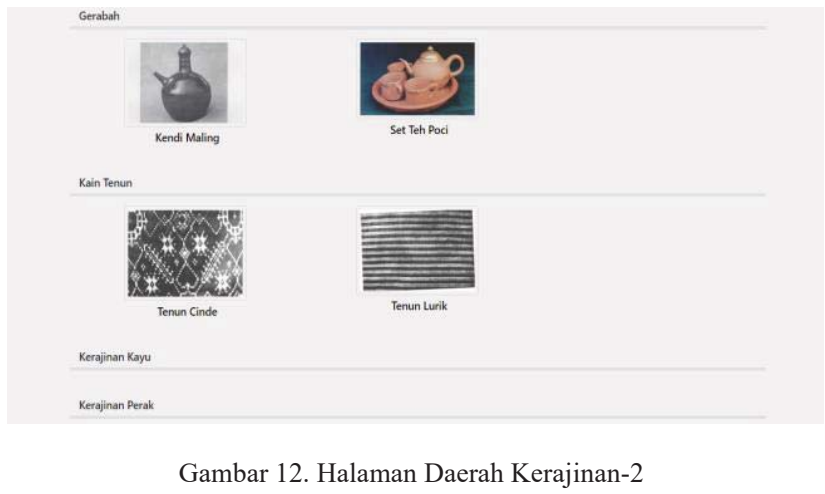

e. Halaman Detail Kerajinan

Halaman detail kerajinan menampilkan detail kerajinan berupa nama, bahan dasar, fungsi, daerah asal dan beberapa informasi lain. Halaman detail kerajinan dapat dilihat pada Gambar 13. 
f. Halaman Motif Kerajinan

Halaman motif kerajinan menampilkan deskripsi motif kerajinan dan jenis-jenis motif kerajinan. Tiap motif kerajinan ditampilkan dalam bentuk button. Apabila button tersebut diklik akan diarahkan ke halaman kerajinan motif. Halaman motif kerajinan dapat dilihat pada Gambar 14.

g. Halaman Kerajinan Motif

Halaman kerajinan motif menampilkan nama-nama kerajinan berdasarkan motif yang sama. Halaman kerajinan motif dapat dilihat pada Gambar 15.

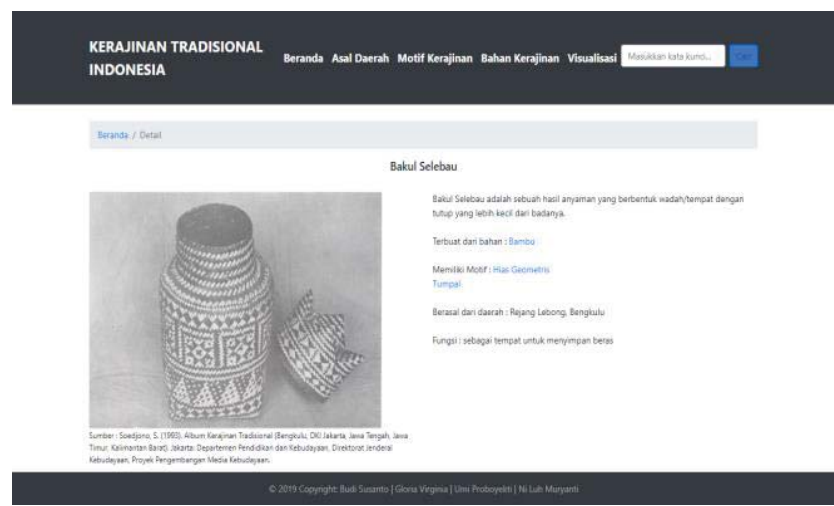

Gambar 13. Halaman Detail Kerajinan

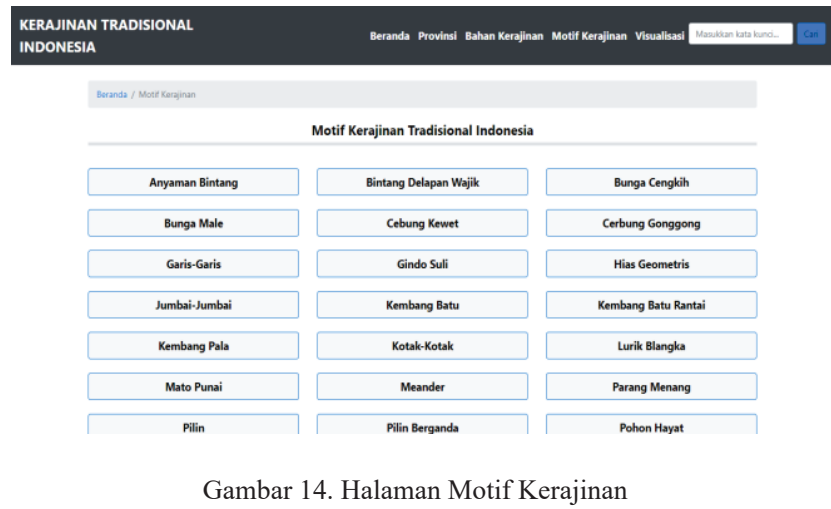

KERAINAN TRADISONAL INDONESIA

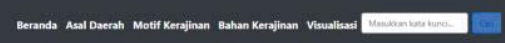

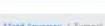
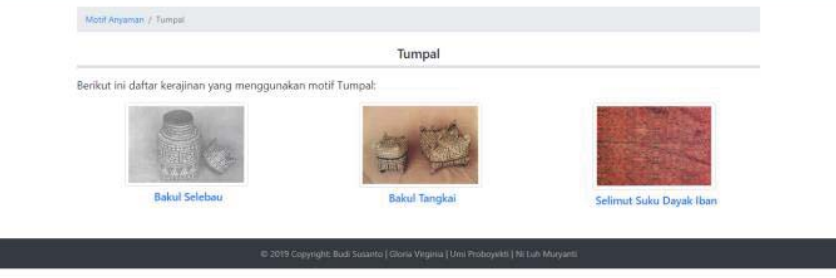

Gambar 15. Halaman Kerajinan Motif

h. Halaman Bahan Kerajinan

Halaman bahan kerajinan menampilkan jenis-jenis bahan kerajinan. Tiap bahan kerajinan ditampilkan bentuk button. Apabila button diklik akan diarahkan ke halaman kerajinan bahan. Halaman bahan kerajinan dapat dilihat pada Gambar 16. i. Halaman Kerajinan Bahan

Halaman kerajinan bahan menampilkan deskripsi dari bahan dan nama-nama kerajinan yang menggunakan bahan yang sama. Halaman kerajinan bahan dapat dilihat pada Gambar 17.

j. Halaman Batik

Halaman batik menampilkan kategori batik yang terdiri dari 2 kagetori. Data untuk kategori batik diambil dari ontologi batik yang sudah ada. Halaman batik dapat dilihat pada Gambar 18.
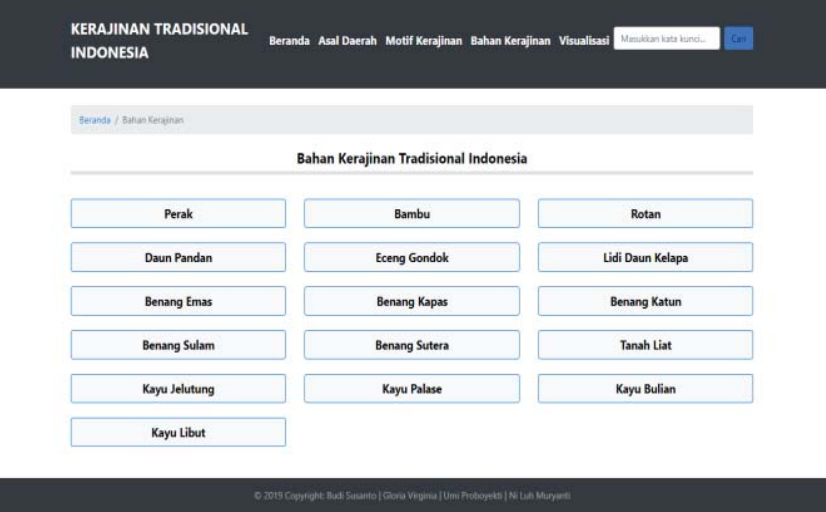

Gambar 16. Halaman Bahan Kerajinan

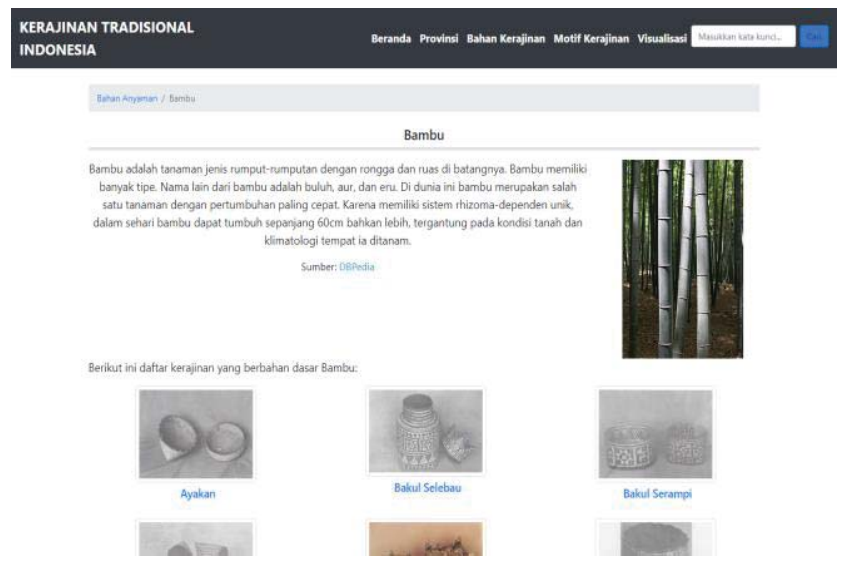

Gambar 17. Halaman Kerajinan Bahan
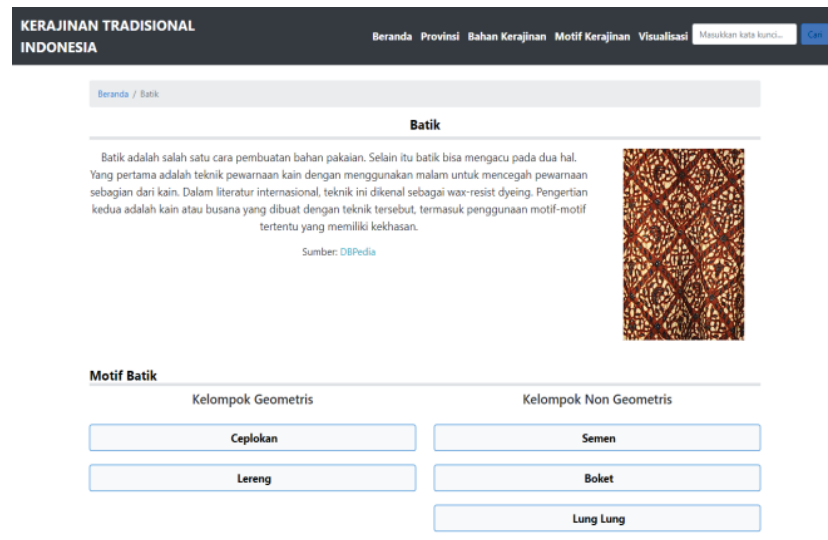

Gambar 18. Halaman Batik 
k. Halaman Hasil Pencarian

Kolom pencarian berada pada bagian header website. Halaman ini digunakan untuk menampilkan hasil pencarian berdasarkan kata yang dicari. Apabila kata yang dicari tidak ada maka akan menampilkan pesan "Data tidak ditemukan". Halaman hasil pencarian dapat dilihat pada Gambar 19.

1. Halaman Visualisasi

Ontologi kerajinan tradisional Indonesia yang telah dibangun dapat divisualisasikan. Hasil implementasi visualisasinya dapat dilihat pada Gambar 20.

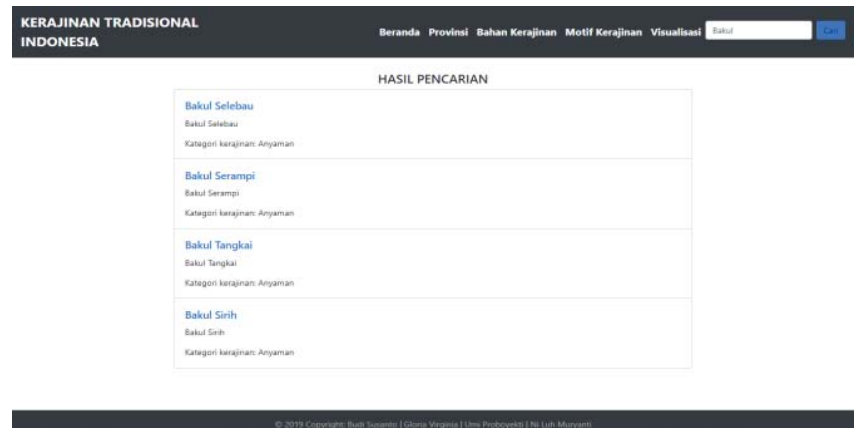

Gambar 19. Halaman Hasil Pencarian

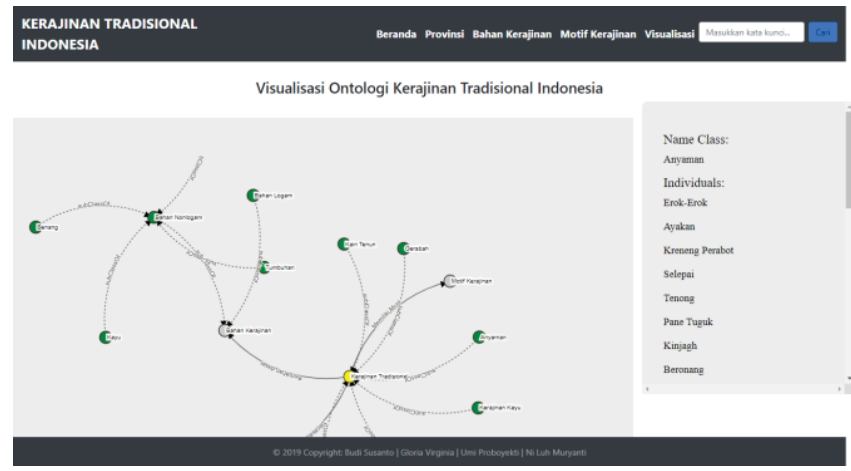

Gambar 20. Halaman Visualisasi

\section{Evaluasi Ontologi}

Proses evaluasi ontologi kerajinan tradisional Indonesia menggunakan 3 cara yaitu consistency, validasi ontologi dan Completeness check.

\section{Consistency}

Pengujian menggunakan reasoner HermiT bertujuan untuk mengukur konsistensi ontologi yang dibangun. Konsisten artinya tidak terjadi konflik antar class, object properties dan data properties. Pengujian menggunakan reasoner HermiT dapat dilakukan secara berulanng selama ontologi dibangun. Jika saat melakukan reasoner terdapat warna merah pada nama class, object properties dan data properties maka ada ketidakkonsistenan pada ontologi. Jika hasil pengujian ontologi kerajinan tradisional Indonesia menggunakan reasoner HermiT tidak menghasilkan eror (terdapat warna merah pada class, object properties dan data properties) maka dapat dikatakan ontologi ini konsisten. Hasil evaluasi dapat dilihat pada Gambar 21.

2. Validasi Ontologi

Pengujian dengan DL query bertujuan untuk membuktikan data yang ada telah sesuai dengan data formal pada ontologi berdasarkan description logic kerajinan

JUTEI Edisi Volume.4 No.2 Oktober 2020

ISSN 2579-3675 , e-ISSN 2579-5538

DOI 10.21460/jutei.2020.42.195 tradisional Indonesia. Contoh hasil evaluasi menggunakan DL Query dapat dilihat pada Gambar 22 dan Gambar 23.

$$
\begin{aligned}
& \text { KerajinanTradisional } \\
& \qquad \text { Anyaman } \sqcup \text { Batik } \sqcup \text { Gerabah } \\
& \sqcup \text { KainTenun } \sqcup \text { KerajinanKayu } \\
& \sqcup \text { KerajinanPerak }
\end{aligned}
$$

\section{Anyaman $\equiv$ KerajinanTradisional \\ $\Pi$ ( $\exists$ memilikiBahan.Tumbuhan)}

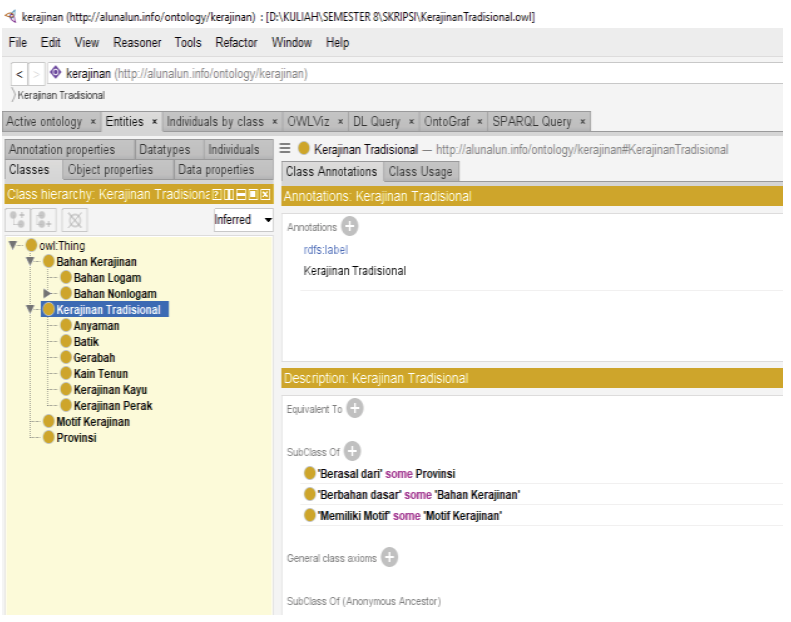

Gambar 21. Hasil Reasoner HermiT

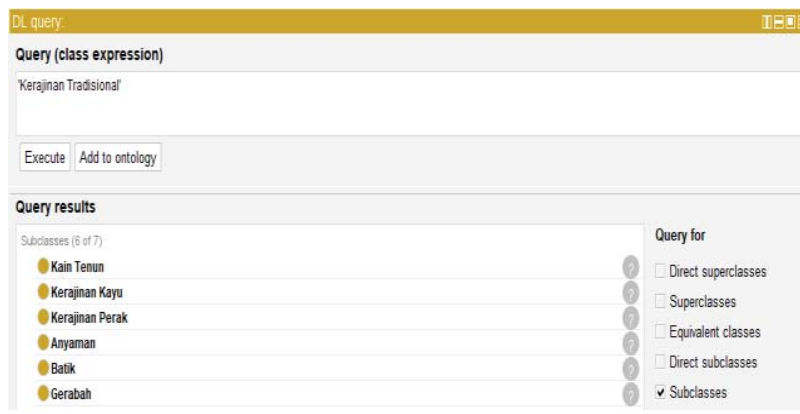

Gambar 22. Hasil DL Query-1

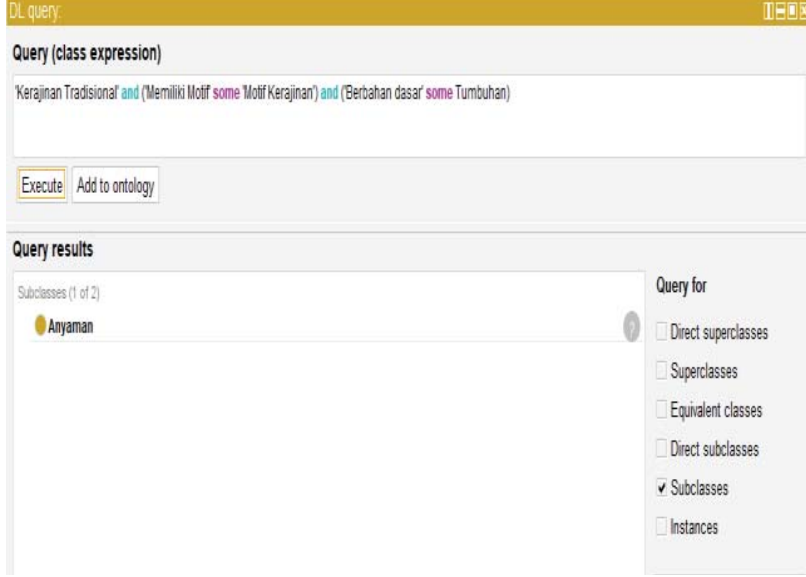

Gambar 23. Hasil DL Query-2 
3. Completeness Check

Pengujian completeness menggunakan parameter competency questions dan DL query untuk menguji kelengkapan data ontologi. Hasil pengujian dibandingkan dengan hasil yang diharapkan yang telah didefinisikan pada Tabel 3. Hasil perbandingan berupa valid dan invalid yang dituliskan pada kolom kesimpulan. Hasil pengujian dapat dilihat pada Tabel 4.

TABEL IV

HASIL PENGUJIAN COMPLETENESS CHECK

\begin{tabular}{|c|c|c|c|}
\hline No & Pertanyaan & Hasil & Kesimpulan \\
\hline CQ1 & $\begin{array}{l}\text { Apa saja } \\
\text { kategori } \\
\text { kerajinan } \\
\text { tradisional } \\
\text { Indonesia? }\end{array}$ & $\begin{array}{l}\text { Sistem dapat } \\
\text { menampilkan } 4 \\
\text { kategori kerajinan } \\
\text { tradisional } \\
\text { Indonesia } \\
\text { Hasil dapat dilihat } \\
\text { pada Gambar } 24 .\end{array}$ & Valid \\
\hline CQ2 & $\begin{array}{l}\text { Apa saja yang } \\
\text { termasuk } \\
\text { anyaman? }\end{array}$ & $\begin{array}{l}\text { Sistem dapat } \\
\text { menampilkan } 23 \\
\text { jenis anyaman } \\
\text { Hasil dapat dilihat } \\
\text { pada Gambar } 25 .\end{array}$ & Valid \\
\hline CQ3 & $\begin{array}{l}\text { Apa saja yang } \\
\text { termasuk } \\
\text { gerabah? }\end{array}$ & $\begin{array}{l}\text { Sistem dapat } \\
\text { menampilkan } 12 \\
\text { jenis gerabah }\end{array}$ & Valid \\
\hline CQ4 & $\begin{array}{l}\text { Apa saja yang } \\
\text { termasuk kain } \\
\text { tenun? }\end{array}$ & $\begin{array}{l}\text { Sistem dapat } \\
\text { menampilkan } 28 \\
\text { jenis kain tenun }\end{array}$ & Valid \\
\hline CQ5 & $\begin{array}{l}\text { Apa saja yang } \\
\text { termasuk } \\
\text { kerajinan kayu? }\end{array}$ & $\begin{array}{l}\text { Sistem dapat } \\
\text { menampilkan } 11 \\
\text { jenis kerajinan } \\
\text { kayu }\end{array}$ & Valid \\
\hline CQ6 & $\begin{array}{l}\text { Apa saja yang } \\
\text { termasuk } \\
\text { kerajinan perak? }\end{array}$ & $\begin{array}{l}\text { Sistem dapat } \\
\text { menampilkan } 2 \\
\text { jenis kerajinan } \\
\text { perak }\end{array}$ & Valid \\
\hline CQ7 & $\begin{array}{l}\text { Apa saja } \\
\text { kerajinan } \\
\text { tradisional } \\
\text { Indonesia yang } \\
\text { memiliki motif } \\
\text { tumpal? }\end{array}$ & $\begin{array}{l}\text { Sistem dapat } \\
\text { menampilkan } 3 \\
\text { kerajinan } \\
\text { tradisional yang } \\
\text { menggunakan } \\
\text { motif tumpal }\end{array}$ & Valid \\
\hline CQ8 & $\begin{array}{l}\text { Apa saja } \\
\text { kerajinan } \\
\text { tradisional } \\
\text { Indonesia yang } \\
\text { menggunakan } \\
\text { bahan dasar } \\
\text { kayu jelutung? }\end{array}$ & $\begin{array}{l}\text { Sistem dapat } \\
\text { menampilkan } 1 \\
\text { kerajinan } \\
\text { tradisional yang } \\
\text { berbahan dasar } \\
\text { kayu jelutung }\end{array}$ & Valid \\
\hline CQ9 & $\begin{array}{l}\text { Apa saja } \\
\text { kerajinan } \\
\text { tradisional } \\
\text { Indonesia yang } \\
\text { berasal dari } \\
\text { Nusa Tenggara } \\
\text { Barat? }\end{array}$ & $\begin{array}{l}\text { Sistem dapat } \\
\text { menampilkan } 4 \\
\text { kerajinan } \\
\text { tradisional yang } \\
\text { berasal dari daerah } \\
\text { Nusa Tenggara } \\
\text { Barat }\end{array}$ & Valid \\
\hline
\end{tabular}

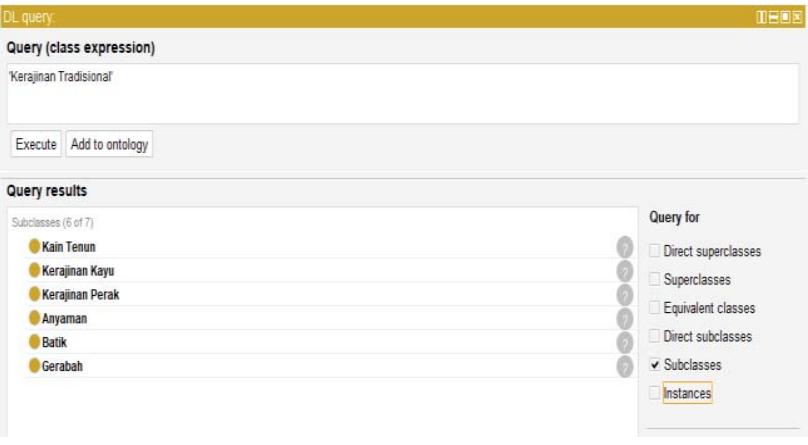

Gambar 24. Hasil CQ1: Apa saja kategori kerajinan tradisional Indonesia?

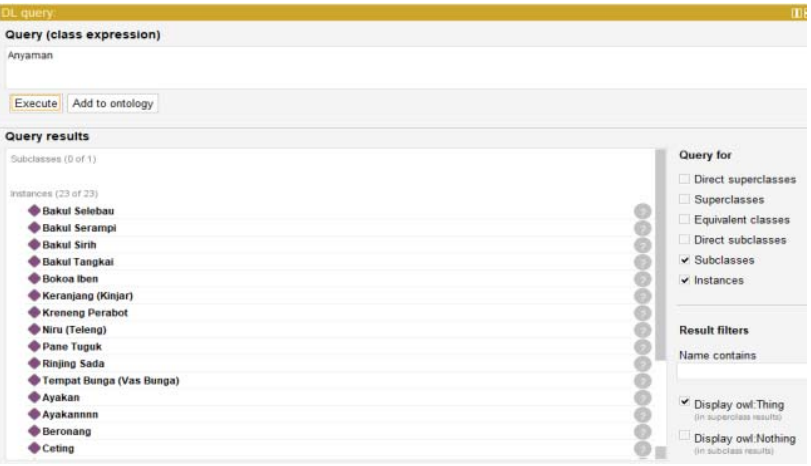

Gambar 25. Hasil CQ2: Apa saja yang termasuk anyaman?

\section{D.Analisis dan Pembahasan}

Ontologi kerajinan tradisional Indonesia yang telah dibangun digunakan dalam pembuatan sistem berbasis semantic web. Sistem yang dibuat tidak hanya menggunakan data dari ontologi kerajinan tradisional Indonesia, namun juga dari ontologi Batik (IRI Batik: http://alunalun.info/batik) dan id.dbpedia.org. Penulis menggunakan properti yang disediakan oleh id.dbpedia.org untuk menampilkan beberapa informasi tambahan untuk objek kerajinan tradisional Indonesia seperti abstrak, comment dan gambar. Namun tidak semua objek kerajinan tradisional Indonesia tersedia di id.dbpedia.org. Penggunaan data ontologi Batik dapat dilakukan dengan cara merge ontologi dan link data. Namun pada penelitian ini penulis menggunakan cara link data. Pengambilan data ontologi Batik dilakukan dengan cara melakukan query untuk menampilkan informasi yang dibutuhkan dari ontologi tersebut.

Pengujian menggunakan reasoner HermiT dilakukan untuk menguji konsistensi ontologi kerajinan tradisional Indonesia yang telah dibuat. Dari hasil reasoner HermiT, dapat dikatakan bahwa ontologi kerajinan tradisional Indonesia sudah konsisten. Untuk validasi ontologi dilakukan dengan pengujian DL Query (Gambar 21 dan Gambar 22) berdasarkan description logic yang telah dibuat. Hasil pengujian sesuai dengan ontologi yang dibangun. Pengujian completeness check bertujuan untuk menguji kelengkapan data ontologi menggunakan parameter competency question seperti pada Tabel 4. Pengujian untuk kelengkapan data dilakukan menggunakan DL Query dapat menjawab semua daftar pertanyaan yang sesuai dengan data dari ontologi kerajinan tradisional Indonesia. 


\section{V.KESIMPULAN}

Berdasarkan implementasi dan analisis yang dilakukan penulis, dapat ditarik kesimpulan yaitu ontologi kerajinan tradisional Indonesia dibangun menggunakan metode On-To Knowledge menghasilkan 4 class utama yaitu class Bahan Kerajinan, Kerajinan Tradisional, Motif Kerajinan dan Provinsi. Ontologi kerajinan tradisional Indonesia berhasil diterapkan kedalam semantic web berbasis OWL.

Model pengetahuan kerajinan tradisional Indonesia mengambil beberapa informasi tambahan dari id.dbpedia.org berupa deskripsi dan gambar serta dari ontologi batik (IRI: http:alunalun.info/batik). Pengambilan informasi tersebut dilakukan dengan menerapkan prinsip linked data yaitu dengan menggunakan query sparql.

Pengujian terhadap ontologi kerajinan tradisional Indonesia menggunakan 3 cara dan menghasilkan ontologi yang konsisten berdasarkan pengujian yang dilakukan.

\section{UCAPAN TERIMA KASIH}

Dalam penyelesain penelitian tugas akhir ini, peneliti telah mendapat banyak bantuan, saran, bimbingan dan dukungan dari berbagai pihak. Oleh karena itu, penulis ingin mengucapkan terima kasih kepada Tuhan Yang Maha Esa, keluarga penulis yang selalu mendoakan, memberikan semangat dalam menyelesaikan tugas akhir, dosen pembimbing I dan dosen pembimbing II yang telah membimbing penulis dalam menyelesaikan tugas akhir, tim proyek alun-alun yang saling membantu dalam menyelesaikan tugas akhir serta semua pihak yang tidak dapat penulis sebutkan yang telah memberikan dukungan dan semangat. Penulis menyadari bahwa masih terdapat banyak kekurangan, baik dalam penelitian maupun dalam penulisan laporan tugas akhir ini. Oleh karena itu, penulis mengharapkan kritik dan saran dari semua pihak.

\section{DAFTAR PUSTAKA}

[1] Aiweb, "A Traditional Craft," [Online]. Available: http://www.aiweb.or.jp/english/dento/html/howto1.html. [Diakses October 2018].

[2] D. Allemang dan J. Hendler, Semantic Web for the working onthologist: Effective modeling in RDFS and OWL, Burlington: Morgan Kaufmann, 2012.

[3] Y. F. Badron, F. Agus dan H. R. Hatta, "Studi tentang Pemodelan Ontologi Web Semantik dan Prospek Penerapan pada Bibliografi Artikel Jurnal Ilmiah," Prosiding Seminar Ilmu Komputer dan Teknologi Informasi, vol. 2, 2017.

[4] S. Staab, R. Studer, H.-P. Schnurr dan Y. Sure, "Knowledge Processes and Ontologies," IEEE Intelligent Systems, pp. 26-34, 2001.

[5] D. Fensel, F. v. Harmelen, M. Klein dan H. Akkermans, "On-ToKnowledge: Ontology-based Tools for Knowledge Management," pp. 1-7, 2000.

[6] N. Ibrahim, "Pengembangan Aplikasi Semantic Web Untuk Membangun Web yang Lebih Cerdas," Jurnal Informatika, pp. 2739, 2007.

[7] A. Susilo, P. W. Handayani dan I. Wilarso, "PERANCANGAN MODEL REPRESENTASI PENGETAHUAN BERBASIS ONTOLOGI PADA APLIKASI SIPELANTIK: STUDI KASUS PUSINTEK KEMENTERIAN KEUANGAN," Journal of Information Systems, vol. 11, no. 2, 2015.
[8] M. B. Ginting, K. B. Seminar dan P. Wasmana, "PENGEMBANGAN SISTEM REPOSITORI PENGETAHUAN BERBASIS ONTOLOGI DAN JARINGAN SEMANTIK (Studi Kasus pada Perpustakaan UNIKA St. Thomas Medan)," Jurnal Perpustakaan Pertanian, vol. 19, 2010.

[9] L. Yu, A Developer's Guide to the Semantic Web, Atlanta: Springer, 2014.

[10] B. Ducharme, Learning SPARQL : Querying and Updating with SPARQL, O'REILLY, 2011

[11] T. Segaran, C. Evans dan J. Taylor, Programming the Semantic Web, Sebastopol: O'Reilly, 2009.

[12] F. Baader dan U. Sattler, "An Overview of Tableau Algorithms for Descriptions Logics," Studia Logica, vol. 69, no. 1, pp. 5-40, October 2001.

[13] F. Baader, D. Calvanese, D. MCGuinness, D. Nardi dan P. F. PatelSchneider, Penyunt., The Description Logic Handbook: Theory, implementation, and applications, Cambrigde University Press, 2003.

[14] S. Abburu, "A Survey on Ontology Reasoners and Comparison," International Journal of Computer Applications (0975 - 8887), vol. 57, November 2012.

[15] S. Soedjono, Album Kerajinan Tradisional (Bengkulu, DKI Jakarta, Jawa Tengah, Jawa Timur, Kalimantan Barat), Jakarta: Departemen Pendidikan dan Kebudayaan, Direktorat Jenderal Kebudayaan, Proyek Pengembangan Media Kebudayaan, 1993.

[16] S. Wisetrotomo, R. Marah dan J. Sanjaya, Album Gerabah Tradisional Kasongan Yogyakarta, Departemen Pendidikan dan Kebudayaan, Direktorat Jenderal Kebudayaan, Proyek Pengembangan Media Kebudayaan, 1995.

[17] I. DENPASAR, "Kerajinan Kayu Di Desa Singakerta," [Online]. Available: http://www.isi-dps.ac.id/berita/kerajinan-kayu-di-desasingakerta/.

[18] KBBI, "Kamus Besar Bahasa Indonesia (KBBI) [Online]," [Online]. Available: https://kbbi.web.id/tenun. [Diakses 09 November 2018].

[19] L. Armiyati, "Industri Perak Kotagede Yogyakarta Melawan Badai Krisis," Sejarah dan Budaya, 2014.

[20] B. Anas, Indonesia Indah : Batik, Jakarta: Yayasan Harapan Kita / BP 3 TMII, 1997.

[21] I. M. Seraya, I. K. Mas, I. M. S. E. Kusuma dan I. N. Wenten, Pengerajin Tradisional di Daerah Bali, Denpasar: Departemen Pendidikan dan Kebudayaan Direktorat Jenderal Kebudayaan Direktorat Sejarah dan Nilai Tradisional Bagian Proyek Pengkajian dan Pembinaan Nilai - Nilai Budaya Bali, 1995.

[22] Y. Affendi, S. Kartiwa, R. Panggabean dan F. Abdullah, Indonesia Indah : Tenunan Indonesia 3, Jakarta: Yayasan Harapan Kita / BP 3 TMII, 1995. 